\title{
COORDINATION: SOUTHEAST CONTINENTAL SHELF STUDIES
}

\author{
A PROGRESS REPORT SUBMITTED TO \\ U. S. DEPARTMENT OF ENERGY \\ Contract EY-76-S-09-0901
}

\author{
BY \\ SKIDAWAY INSTITUTE OF OCEANOGRAPHY \\ P. O. BOX 13687 \\ SAVANNAH, GEORGIA 31406
}

This report was prepared as an account of work sponsored by the United States Government. Neither the United States nor the United Staves, nor any of their Energy, nor any of their emplos their employees, makes contractors, subcontractors, or the or assumes any lega

any warranty, express or implied, or aracy, completeness

liability or responsibitity for the appatus, product or

liability unesulns of any information, apparat se would no

process disclosed, or represents

infringe privately owned rights.

DAVID W， MENZEL

PRINCIPAL INVESTIGATOR

12 FEBRUARY 1979 


\section{DISCLAIMER}

This report was prepared as an account of work sponsored by an agency of the United States Government. Neither the United States Government nor any agency Thereof, nor any of their employees, makes any warranty, express or implied, or assumes any legal liability or responsibility for the accuracy, completeness, or usefulness of any information, apparatus, product, or process disclosed, or represents that its use would not infringe privately owned rights. Reference herein to any specific commercial product, process, or service by trade name, trademark, manufacturer, or otherwise does not necessarily constitute or imply its endorsement, recommendation, or favoring by the United States Government or any agency thereof. The views and opinions of authors expressed herein do not necessarily state or reflect those of the United States Government or any agency thereof. 


\section{DISCLAIMER}

Portions of this document may be illegible in electronic image products. Images are produced from the best available original document. 
OVERVIEW DOCUMENT

SOUTHEAST OCEANOGRAPHIC PROGRAM 
PROPOSED GABEX-FRNFLX EXPERIMENTS (1979-1982)

SOUTHEAST OCEANOGRAPHIC PROGRAM

(Sponsored by the U. S. Department of Energy)

\section{MID- TO OUTER CONTINENTAL SHELF RESEARCH}

Research efforts on the southeast continental shelf are currently describing the manner in which fluctuations in Gulf Stream motion influence biological and chemical processes. Current meter arrays are being maintained in the Georgia Bight and in Onslow Bay to describe general circulation patterns and to identify forcing functions. Biological studies are describing processes affecting temporal and spatial variations on the shelf and have attempted to track the biological history of intruded Gulf Stream water masses. Chemical studies examine the influence of both physical and biological variables on the distribution and fate of trace elements. The following outline and discussion reviews our current state of knowledge, describes hypotheses developed and provides a rationale for testing these hypotheses.

\section{Current State of Knowledge}

\section{Physical}

(1) The shelf can be divided into two flow regimes with different driving forces and exchange properties:

(a) Outer shelf where Gulf Stream processes such as meanders and eddy shedding control current variability and the residence time of water is 2-10 days.

(b) Inner and mid-shelf regions where currents are dominated by winds and tides in the winter. During the summer density 
driven flows may be important and Gulf Stream effects appear to extend: to the mid-shelf region. The residence time of midcontinental shelf waters is in the order of several months.

(2) Gulf Stream eddies and meanders are associated with the upwelling of cool deep Gulf Stream water along the outer shelf. Eddies have been observed to produce counterclockwise flow. Meanders and eddies propagate to the north and grow in size north of the "Charleston Bump".

(3) Gulf Stream eddies increase the flux. of materials onshoreoffshore along the shelf edge. In the case of nutrients and trace elements the net flux is onshore near the bottom.

(4) Individual eddies may upwel1 $200 \mathrm{~km}^{3}$ of water (over one eddy length) containing $>3000$ tons of nitrogen.

(5) In the summer eddies and wind forcing can cause water to upwell onto and intrude across the shelf of north Florida, Georgia and the region of the Carolina Capes. Intrusions are more common in the northeast Florida and Carolina Cape regions than off Georgia and may be identifiable for up to one month. Subsurface intrusions upwelled off northern Florida are driven northward by prevailing winds.

(6) Coherence of alongshore currents at mid-shelf locations between Savannah and Cape Fear is high during the winter due to similar responses to traveling metoerological disturbances. Coherence of onshore-offshore currents is low. Coherence of alongshore flow is low across the shoals associated with Carolina Capes.

(7) Wind forcing appears to follow Ekman frictiolal e...: : brium concepts. Northwest winds cause a coherent set-down of coastal sea level, offshore transport in the upper layer and onshore 
motion in the lower layer. This results in a cross-shelf pressure gradient in approximate balance with northwest currents over the shelf. The opposite occurs during southerly winds.

\section{Biological}

(8) Biological production primarily involves microorganisms with short generation times. Whether these components transfer significant energy to higher organisms depends on the residence times of the water, which is variable. This feature may explain some of the variability in biological production on the shelf.

(9) Most of the southeast outer continental shelf water is low in nutrients, chlorophyll, and adenylates. Energy charge is less than 0.5. Occasional areas of high chlorophyll and adenylates, with energy charge greater than 0.5 , are associated with movements of water from the west wall of the Gulf Stream onto the continental shelf. These are the only areas of moderate to high productivity of microheterotrophs on the outer shelf.

(10) Several intrusions have been located and followed over limited periods of time. Phytoplankton and microbial heterotroph response to nutrient-rich intrusions is rapid with first response at the interface of the intrusion with shelf water. Chlorophyll concentration and energy charge rise rapidly in a patchy way above the intrusions and at the thermocline.

(11) Primary production rates may exceed 2 grams $c / \mathrm{m}^{2} /$ day within zones of active upwelling compared to an average shelf value of 0.3. A significant fraction of this productivity can be accounted for by diatoms such as Skeletonema costi....: and Asterionella japonica. During the passage of eddies nitrateenriched water may reside within the euphotic zone on the 
shelf for only 2-5 days, an insufficient time for most to be utilized by phytoplankton. In the summer subsurface intrusions of nutrient-rich Gulf Stream water, on the other hand, can strand on the shelf for 2-4 weeks. Intense phytoplankton blooms are induced which deplete the nitrate in about 14 days.

(12) Young intrusions are characterized by high concentrations of phytoplankton of 10 to $100 \mu \mathrm{m}$ cell diameter. Old intrusions have relatively low concentrations of cells $<20 \mu \mathrm{m}$ in diameter.

(13) Summer intrusions are dominated in number and biomass by sniall copepods (Cyclopoida, Paracalanidae), including naupliar and copepodid stages which graze small cells exclusively (see 12).

(14) Shelf break events during April are characterized by high. concentrations of pelagic tunicates, fish larvae and breeding populations of sergestid shrimps.

\section{Trace Element Chemistry}

(15) Mass balance calculations, which assume complete mixing of intruded waters, indicate that intrusions control the concentration of and are the main source of trace elements to shelf waters.

(16) Nutrient and dissolved trace element concentrations in Gulf Stream waters appear interrelated.

(17) Molar metal:nitrogen ratios in suspended particles on the shelf approximate those ratios derived from regressions applied to dissolved fractions in deep ocean vertical profiles.

\section{Hypotheses}

The following hypotheses are derived from the above observations:

Physical

(1) Diverging isobaths in the lee of Cape Canaveral enhance cyclonic 
vorticity which encourages shelf-scale upwelling and more intense stratification in the sumer off northeast Florida than off Georgia.

(2) Upweliing produced by eddies and meanders on 2-10 day time scales may penetrate to shallower depths on the northeast Florida than on the Georgia shelf.

(3) Cross-shelf fluxes of heat, momentum and nutrients are greater off northeast Florida than off Georgia.

(4) Shelf waters respond in an analogous fashion to traveling meteorological disturbances over the topographically similar region from Cape Canaveral to Cape Fear. This response is believed to follow Ekman frictional equilibrium dynamics.

(5) The development of seasonal, shelf-scale stratification occurs rather suddenly in late spring and early summer due to the nearly simultaneous occurrence of intensifying cross-shelf density driven circulation and decreasing wind-induced vertical mixing.

(6) During the summer Gulf Stream forcing events may extend into mid-shelf regions.

(7) Southward geostrophic flow may develop over the shelf in the summer due to sloping density surfaces.

\section{Biological}

Physical forces control water movement on the shelf and thus the structure and function of the food web. Depauperate shelf fauna may result from the nature of the food web or because residence time of nutrient enriched water on the shelf is too short to permit the full developinent of consumer populations. 
(8) Phytoplankton may not respond fast enough during eddy forced upwelling to fully utilize all availabie nutrients. The opposite is true when intrusions strand on the shelf or when upwelling is persistent at a given location.

(9) Near the shelf break gradients in mixed layer microorganismphytoplankton concentrations differ markedly prior to, during and after the passage of an eddy.

(10) Phytoplankton formed in subsurface Gulf Stream intrusions support the production of one copepod generation but after three weeks the concentration of small particies ( 3 to $15 \mu \mathrm{m}$ ) is too low to support the development of a second generation.

(11) Strong vertical density gradients on the shelf during the summer minimize the number of zooplankton entering subsurface Gulf Stream intrusions from the upper mixed layer thus reducing their impact on phytoplankton within the intrusion.

(12) The main predatory impact on juvenile copepods is not from obligate carnivores like chaetognaths but from late copepodids and adults of most omnivorous-facul tative carnivorous copepods.

(13) Significant amounts of phytoplankton produced in intrusions may be utilized by nekton (i.e., menhaden) or benthos rather than by zooplankton.

(14) Enhanced persistent upwelling in the region of diverging isobaths (e.g., lee of Cape Canaveral) provide sufficient continuing nutrient input to support localized high concentration of benthic filter feeders (e.g., scallops). 


\section{Trace Element Chemistry}

(15) Within intruded waters trace elements are biologically converted from soluble to particulate form. Depending on the extent of conversion and the fate of particulate trace elements conclusions based on past mass balance calculations may be a) tered.

(16) Dissolved nutrient-trace element relationships may be reflected in the elemental compositon of particulates. Consequently prediction of the fate of trace elements intruded onto the shelf may be largely a function of shelf nutrient dynamics.

Research Plan

Rationale

Currents on the shelf and upwelling at the shelf break are products of direct wind forcing and forcing by the Gulf Stream. The resulting circulation profoundly influences biological and chemical processes on the shelf. Transfer of energy from wind and the Gulf Stream to the waters overlying the shelf depends on the strength of any given event and on the existing density structure of the shelf. The resulting shelf currents at a given location thus reflect the strength of forcing, the state of the density structure, the bottom bathymetry and the character of the coastiine in locations close to shore. All occur on dramatically differing time and space scales.

Momentum transferred to the shelf by Gulf Stream eddies may vary as eddies travel northward. Circulation patterns differ seasonally but how they differ is largely unknown. The modification of the currents as they "feel" the presence of thr -horline, inlets and shallow bottom is likely to differ between nortic: : f Florida and Georgia. Synoptic measuremements of currents between Georgia and Cape Canaveral must meet 
several scaling criteria. They must span seasonal changes in the shelf's density structure and yet measure currents with sufficient frequency to cover enough Gulf Stream eddies and wind events (20 to 30 each season) to derive significant statistics for the flow regime at each location. The array of moored instrumentation described below is designed to meet this general requirement. Hydrodynamic models of shelf circulation may eventually be required to predict the circulation regimes resulting from wind and Gulf Stream forcing. The large-scale array will provide a valuable data base of flow from which such models, if required, can be verified over event and seasonaj time scales.

Earlier stated hypotheses will be tested by conducting eventoriented experiments (GABEX I and II). We will seek out and study water masses spawned from Gulf Stream disturbances that intrude onto the shelf. These may be small stranded intrusions of modified Gulf Stream water which are found along the length of the outer shelf from Cape Canaveral to Savannah and which occur on frequences of 2 days to 2 weeks. Modified Gulf Stream water may also extend across the entire shelf off northeast Florida, the scale and residence time of which is much larger than small stranded intrusions. These investigations will examine why intrusions occur on different scales and determine their time related effects on chemical and biological processes.

GABEX I event cruises are planned during the winter-spring (1980) when the shelf changes from a vertically well-mixed regime to one that becomes highly stratified off northeast Florida and weakly stratified off Georgia. GABEX II event cruises will take place during the summerfall of 1981 or 1982 when the shelf hydrography reverts to a more vertically homogeneous winter state. We expect to find modified fulf ctrnam 
water intruded well onto the shelf off northeast Florida during GABEX 11.

Implementation

Current Meter Arrays

Circulation patterns and current variability over the continental shelf between Cape Canaveral and Savannah will be measured over fourmonth periods overlapping both GABEX I and GABEX II. The timing of these experiments is shown in Table 1. An array of current, temperature, salinity, bottom pressure and inverted echo sound recorders and one instrumented meteorological tower (Figure 1) will provide data to allow us to compare circulation regimes on the northeast florida shelf with the shelf off Georgia. Acquired data will aid in interpreting events studied on GABEX I and II cruises and will examine the coupling and exchange of momentum heat and salt between the nearshore frontal zone, continental shelf waters and the offshore Gulf Stream.

A box-shaped current meter array located off Savannah, Georgia (partially supported by BLM through 1979) has yielded sufficient background information during the winter to allow us to design the GABEX I array. The GABEX II array design will be similar unless analyses of data from the existing summer box array yields unexpected results. Basic knowledge utilized in designing the proposed GABEX arrays is coherence analysis for temperature and for along-shelf and cross-shelf flow. The limiting alongshore spacing is at the shelf break where at depths deeper than 50 meters the minimum alongshore coherence distance is about $50 \mathrm{~km}$. This is the minimum distance required to resolve the cross-shelf flow field due to eddy motion. Spacing in areas shallower than 50 meters can be increased to $100 \mathrm{~km}$ alongshore. 
An important object of the GABEX arrays is to contrast shelf response to Gulf Stream disturbances as these disturbances propagate downstream along the shelf break. Theoretical considerations indicate that the diverging isobaths north of Cape Canaveral induce upwelling by increasing the vorticity of the circulation. To evaluate this process we will moor current meters at the $15,25,30,40$ and $75-m$ isobaths since all but the $75 \mathrm{~m}$ isobath diverge significantly north of Cape Canaveral.

The along- and cross-shore spacing of current meters should be sufficient for us to follow the propagation of wave-like disturbances downstream and to test previously stated hypotheses.

Moorings located at the $15 \mathrm{~m}$ isobath are designed to obtain current measurements within the inner $20 \mathrm{~km}$ of the shelf--the nearshore zone. We plan to investigate and compare the response of the nearshore zone to wind-generated mid-shelf responses. Two of the nearshore moorings are off the coast of northeast Florida where inlets are widely spaced and infrequent. Off Georgia, the coastline is heavily indented with inlets which store various amounts of tidal water. The effects of inlets off Georgia on the nearshore circulation will be studied with an L-shaped mooring array whose apex is formed by the Savannah River Navigational Light Tower (depth $=15 \mathrm{~m}$ ). Cross-shore locations will be at the 20, 18 , and $15 \mathrm{~m}$ isobaths where the alongshore spacing will be about $20 \mathrm{~km}$, or one-half the spacing of the prominent "inlet" channels located outside the tidal deltas of each major inlet.

Summary of Information To Be Obtained from the Moored Arrays

(1) Estimates of the seasonally averaged shelf volume transport and circulation patterns after the response to wind and Gulf Stream events have been averaged out for each mooring period. 
(2) Measurement of the generation and decay of seasonal shelfscale stratification on the northeast Florida and Georgia shelves.

(3) The detailed response of shelf waters to Gulf Stream and wind forcing everits during well-mixed winter conditions, vertically stratified summer conditions, and during transitions between the two hydrographic regimes.

(4) The shelf break flux of momentum, heat, salt and nutrients off northeast Florida will be contrasted to that off Georgia to test the hypothesis that diverging isobaths enhance upwelling off northeast Florida.

(5). Flow regimes on the nearshore shelf under the influence of the many tidal inlets off Georgia to the mid-shelf $(25 \mathrm{~m}-30 \mathrm{~m}$ isobaths) and net (tides removed) nearshore transport off northeast Florida and off Georgia will be compared.

(6) Compute vertical velocities from shelf data.

\section{Shipboard Observations}

GABEX I and II cruises will involve the simultaneous use of two oceanographic research ships. One will track Gulf Stream events on the outer shelf for approximately 20 days using surface temperature, salinity mapping and near real time satellite thermal images. This ship will measure changes in volume, heat, salt, trace elements, nutrients, and biological communities over a significant portion of the lifetime of the event. The other vessel will repeatedly sample a fixed hydrographic and biological grid and thus observe the passage of events through the shelf waters while measuring associated physical, chemical and biological interations. 
Satellite observations show that eddies pass a given shelf break location each 3 to 10 days and our past observations of shelf break currents verify this time scale. Thus, it may be expected that two or three eddies exist in the region between Cape Canaveral and Savannah at any given time. Near real-time satellite thermal images will be used to guide the research vessel to the region of an eddy for intensive observation of biological and chemical processes associated with the eddy event.

Biological-Chemical Observations

(1) Abundance, energy state, growth rate of bacteria, nannoplankton, and other microorganisms and changes with time as succession proceeds in and around the intrusions will be determined.

(2) Our quantitative understanding of the fate of nitrogen within intruded water, after an initial 10 to 14 day period in which nitrate is converted into phytoplankton biomass, is limited. To approach this problem we will look for changes in the size of the various dissolved and particulate pools as the intrusion "ages" on the shelf. We will also measure the same nitrogen pools in the surface mixed layer overlying the intrusion to determine if nitrogen is transferred through the thermocline. We are particularly interested in whether total nitrogen is conserved within the water column as a net loss would indicate export to the benthos or possibly to pelagic fish. Our assumption is that physical exchange processes across the horizontal boundaries of the intrusion occur at a much slower rate than the biological processes within the intrusion. During the suminer of 1979, Pat: ffer and Yoder plan to address this 
problem. After completion of the summer study we will be in a better position to define GABEX II experiments in detail.

(3) The vertical and horizontal concentration of particles in upwelled water and in the upper mixed layer will be related to zooplankton abundance and composition. From previous experience we expect to find reproducing or growing zooplankton populations in the dense phytoplankton layer. The state of reproduction and growth vs. phytoplankton and nutrient density will indicate the state of zooplankton production.

(4) Rates of change in temperature, nitrate and phytoplankton concentrations will be used to estimate when upwelling started and an intrusion moved on to shelf, this to provide an index which may be used to "date" other intrusions.

(5) Changes in primary production and particle size concentration over time will describe the amount and size of matter available to zooplankton.

(6) Diurnally spaced vertical profiles will quantify changes in the concentrations of juvenile and adult zooplankton in the upper mixed layer, the thermocline and the intrusion over time allowing an estimate of the production rate of selected zooplankton taxa.

(7) Time sequence analyses of soluble and particulate concentrations of trace elements and the relation of the removal rates of these elements from solution to nutrient utilization will permit prediction of the fate of metals intruded onto the shelf from subsurface Gulf Stream waters. 


\section{NEARSHORE RESEARCH}

The nearshore zone off Georgia is characterized by turbid water of somewhat lower salinity than clearer open shelf waters about $20 \mathrm{~km}$ offshore. Many tidal inlets eject fresher water onto the shelf which overrides the more saline shelf water. The nearshore zone is strikingly similar in structure to that of a partially mixed estuary except that the lateral boundary extends for several hundred kilometers while the length is only $10-20 \mathrm{~km}$.

Materials transported from the shore to the middle continental shelf, or conversely from mid-shelf to nearshore, are advected and dispersed by tidal currents. Circulation is also influenced by density differences between the turbid fresher water overlying saltier open shelf water. In other words, transport and dilution rates of pollutants advected into the nearshore zone are governed by tidal and wind generated currents which in turn interact with horizontal and vertical density gradients of the frontal zone. Particulate matter injected into this environment has a wide range in size and composition. These particles settle at different rates which under the influence of turbulent mixing due to tides and surface waves may be resuspended. Particulate matter also changes chemically as it passes through salinity gradients. Thus, the fate of materials is influenced by (1) the nearshore front formed by fresher water emanating from the many estuaries, (2) circulation between adjacent inlets, (3) transport caused by wind and density generated currents, and (4) exchange with the shelf waters. While some information on (2), (3), and (4) will evolve from shelf studies described earlier, experiments specifically designed to understand the hydrography of the nearshore zone are required to evaluate the role of neir'shor: i, onts in governing the fate of materials. 
Our understanding of the nearshore zone is severely limited in that salinity fronts form an "interface" with the open continental shelf at one boundary and many estuarine inlets at the other. The coupling of these two systems is not understood. Our general objectives are to:

(1) determine the chemical characteristics and input rates of selected trace elements and radionuclides to the nearshore 2one;

(2) determine the environmental conditions under which these elements exchange with offshore waters or, conversely, are trapped in the nearshore zone; and

(3) determine their transport and cycling within the zone (i.e., from inlet to inlet and between sediments and water column).

Several basic scientific questions must be answered before the broad objectives stated above can be met. These questions will be addressed by conducting a series of long-term/seasonal studies and site specific shorter term experiments (Front Flux Experiments (FRNFLX)) which are described below.

- How does the flux of salt and other materials differ with distance offstiore?

- How does vertical mixing through the frontal zone change with distance offshore?

- What is the size distribution of particulate matter and how does this change with depth and during the tidal cycle?

- Is it correct to treat the nearshore zone as a partially mixed, infinitely wide estuary (i.e., do alongshore variations in offshore flux differ greatly near the edge of the nearshore zone)?

- How do the concentrations of dissolved and particulate trace elements and radion's? ides (matter) vary during a tidal cycle at different distances irom shore? 
Long-Term and Seasonal Observations

1. We will continue to monitor currents, temperature, sea level and meteorological parameters at the Savannah River Navigational Light Tower. Capability to measure conductivity at the water current sensors will be added in sumer 1979. We propose to operate the Tower continuously until GABEX II is completed. The following questions will be addressed:

(a) Does the net alongshore drift correspond to the net wind stress?

(1) Episodes of northeast wind stress and southwest wind stress will be isolated.

(2) The wind stress episodes will be correlated to the corresponding strengths of currents with tidal frequencies removed.

(b) What oceanographic conditions can enhance the likelihood that effluents from one inlet may be transferred to the tidal influence of an adjacent inlet?

(1) The tidally filtered currents and the alignment of their current ellipses may vary between low and high runoff conditions.

(2) The alignment of the tidal current ellipses may change between low and high runoff conditions.

2. Elevated tritium concentrations in Savannah River water provide a unique tag for tracing movements of the effluent. The processes of inlet to inlet transfer and mixing in the nearshore zone can be studied with these data. Specific questions are:

(a) Under what conditions can effluents from one river reach an adjacent inlet? 
(b) What dilutions of Savannah River water are measured in adjacent inlets?

Time-integrated samples will be collected near the entrances to several inlets adjacent to the Savannah River and at the Savannah River inlet itself. The samplers will collect water for tritium analysis over a period of several storm cycles (1-2 weeks) with tidal variations averaged out. Two or three experiments each will be realized during periods of low and high runoff. Current data from the instrumented tower, corresponding to the experimental periods, will be utilized to interpret tritium concentrations at the sampling locations.

3. Geochemical studies will be conducted in the nearshore zone to evaluate trace element and radionuclide partitioning between dissolved and particulate phases and between bottom sediments and the water column. In addition to FRNFLX experiments described below we will occupy transects across the turbid zone in different seasons. Sediments and water will be sampled at locations based on topography and circulation patterns established during. FRNFLX. These samples will be analyzed to determine accumulation rates and depths of sediment reworking.

4. Biological studies will address the following questions by periodic transects across the nearshore fronts.

- Is coastal front structure as such significant to basic biological processes, or is the impact only that of estuarine and river outputs?

- Particles in suspension are surfaces on which chemical and biological processes may take place, but they also attentuate light.

- What are the optima of these interactions in terms of turbidity, particle size, particle type and distance from shore? 
Front Flux Experiments (FRNFLX)

Background Knowledge

(1) Alongshore wind stress nearshore off Georgia is predominantly north to northeastward from December to August and south to southwestward from September to November.

(2) A well-defined turbid zone, which results from fresher sedimentladen water ejected from the coastal marshes and rivers, exists in the inner 10 to $20 \mathrm{~km}$ between Cape Romain, SC, and Fernandina Beach, FL.

(3) The offshore flux of fresh water is controlled mainiy by tides and their interaction with vertical density gradients.

(4) The nearshore zone is a sink for particulate matter coming down rivers and can partially trap trace elements and radionuclides.

In May 1978 a preliminary experiment was conducted with two ships simultaneously anchored through 4 tidal cycles in the nearshore frontal area. These ships were each anchored at the 13-meter depth contour 5 nautical miles apart (about one-half the inlet spacing off Georgia). Our object was to investigate differences in salt flux as generated by tidal currents and vertical density gradients of the frontal zone. The ships were spaced at almost the same distance offshore to see if lateral differences in measurements complicate interpretation of chemical and biological data. While this would pose a problem close to the inlets themselves, our working hypothesis is that beyond the influence of the tidal ebb plumes emanating from each tidal inlet the turbid water goes through several cycles of tidal mixing and the resulting mixture of water from several tidal inlets is more or less homogeneous. The problem becomes one of taking observations far enough offshore to be in the more 
homogeneous water. Data from the May 1978 experiment have not been completely synthesized, but early indications are that future experiments should be located slightly farther offshore than 5 miles. Major Questions To Be Addressed

Transport Processes

(1) How does total salt flux compare between high and low runoff conditions; how do tidal and gravitational components compare?

(2) Particles are a vehicle for trace element transport. What are the particle-size spectra; how do the spectra change over a tidal cycle and with distance offshore?

(3) Richardson numbers represent a ratio of buoyancy forces that inhibit the vertical transport of dissolved and small suspended particles to the dissipation of turbulent energy that enhances the vertical transport. How does this parameter change over a tidal cycle and across the nearshore zone? What differences are observed during low versus high runoff conditions?

(4) How is river waer diluted and transported in the nearshore zone? Sedimentation Processes

(1) How does particle size change with distance offshore? What settling rates can be attributed to the different size fractions?

(2) The inclined frontal zone separates the fresher water derived from the estuarine areas from the open shelf water. How do particle sizes differ in these two water masses and how do they differ under different runoff conditions?

\section{Resuspension Processes}

(1) Are large particle sizes associated with strong tidal currents? Does particle size near the bottom correlate witi li: strength of tidal currents. 


\section{Chemical Processes}

(1) How does trace element chemistry vary with particle size? How does the chemistry vary across the nearshore zone between high and low runoff conditions?

(2) How do the trace element and radionuclide concentrations vary under different runoff regimes? How do the concentrations vary with salinity?

\section{Biological Processes}

(1) How do primary and secondary productivity relate to coastal fronts? Is there a relationship between frontal development and the known regions of high coastal productivity, or is productivity related directly to outputs from rivers and estuaries?

(2) What are the interactions between turbidity, vertical mixing (Richardson numbers), and productivity?

\section{Implementation}

Two nearshore experiments are proposed. Each will use two ships simultaneously anchored in the nearshore zone over 4-5 tidal cycles. One experiment will be conducted under conditions of low runoff (autumn 1979; FRNFLX I) and the other during high runoff conditions (spring 1981; FRNFLX II). One ship will be located halfway across the nearshore zone, after this distance has been determined by hydrographic survey, and the other will be located closer to the offshore extremity. The onshore-offshore tidal currents will move the inclined subsurface frontal zone past each ship whlle measurements of salinity, temperature current profiles, chlorophyll and light attentuation will be made. These measurements will be interpreted immediately to ascertain the best location for large water samples required for trace elt" 5 , radionuclide particlemsize, and nutrient analyses. Profiles will be averaged over depth to calculate 
the flux of salt past each ship. Deviations of individual profiles from the depth average will yield the portion of the salt flux induced by the vertical density gradient of the frontal zone. Coefficients of offshore tidal diffusion will be estimated by comparing differences in vertically averaged salt flux during a tidal cycle over the distance separating the two ships. These techniques have been applied extensively to calculate salt flux in estuaries. Tritium levels will be measured to determine the transport and dilution rates of Savannah River water.

The FRNFLX experiments are designed to answer the questions itemized above. A summary of the measurements and analyses required to answer each question are now given. Each measurement will be taken every two hours over 4-5 tidal cycles at 2 locations.

\section{(1) Physical Transport Processes}

(a) Vertical profiles will be obtained of current velocity, temperature and salinity.

(b) Tidal fluxes will be computed from vertical averages.

(c) Gravitational fluxes will be computed from deviations from vertical averages.

(d) Richardson numbers will be derived from profiles of density and velocity shear.

(e) Tritium concentrations will be correlated with salinity values.

(2) Sedimentation Processes

(a) Vertical profiles of temperature, salinity and light attenuation will be used to identify the location of the maximum density change (frontal zone) that separates the nearshore turbid zone from the underlying shelf waica;

(b) particle size spectra using a.Coulter Counter will be obtained from bottle samples in each water mass; 
(3) Resuspension Processes

(a) Using water samples obtained 1-meter above bottom we will attempt to correlate the concentration of particles of larger than $>50 \mu$ with bottom current velocity;

(b) Lead-210 profiles in sediment cores will be determined (see 4. c. below).

(4) Chemical Processes

(a) Trace element and radionuclide chemistry will be compared with observed particle size spectra;

(b) Dissolved trace elements and radionuclides will be correlated with salinity data.

(c) Several radionuclides in the uranium-thorium decay series may also be useful as water/sediment tracers. $\mathrm{Pb}-210$ will be measured to determine the age of recent sediments $(<100$ years) to help evaluate sediment transport and fate. Po$210 / \mathrm{Pb}-210$ ratios will be measured to estimate chemical fractionation which may occur in the turbid zone. Other isotopes such as Ra-228 may be measured to determine chemical diffusion across the turbidity front.

(5) Biological Processes

(a) Profiles of chlorophyll a will be correlated with the profiles of light attentuation and particle concentration.

(b) Changes in microbial numbers and morphology will be compared with particle concentration and size spectra;

(c) Critical depths will be estimated and evaluated relative to productivity. 
